\title{
Pengaruh Sikap, Dukungan Teman Sesama Wanita Pekerja Seks (WPS) dan Motivasi terhadap Perilaku Pencegahan HIV/AIDS WPS
}

\author{
Nina Sri ${ }^{1}$, Catur Septiawan $G^{2}$ \\ ${ }^{1}$ Sekolah Tinggi Ilmu Kesehatan Prima Indonesia \\ ${ }^{2}$ Sekolah Tinggi Ilmu Kesehatan Indonesia Maju \\ ${ }^{1}$ Jl. Raya Babelan km 9,6 Kelurahan Kebalen, Kecamatan Babelan - Kab. Bekasi, Indonesia Telp: (021) 89134519 \\ ${ }^{2}$ Jl. Harapan Nomor 50, Lenteng Agung - Jakarta Selatan 12610, Indonesia Telp: (021) 78894043 \\ Email: ${ }^{1}$ ninasri@stikesprimaindonesia.ac.id, ${ }^{2}$ uima.penjaminmutu@gmail.com
}

\begin{abstract}
Abstrak
HIV (Human Immunodeficiency Virus) merupakan suatu virus yang menyerang sistem kekebalan tubuh manusia dan melemahkan kemampuan tubuh untuk melawan penyakit yang datang. Tertularnya seseorang dengan HIV ini akan menyebabkan orang tersebut menderita sakit AIDS (Acquired Immunodeficiency Virus). Salah satu kelompok beresiko tertular penyakit ini adalah wanita pekerja seks (WPS) karena perilakunya yang cenderung berhubungan dengan banyak pelanggan. Tujuan penelitian untuk mengetahui pengaruh langsung dan tidak langsung serta besaran sikap dalam pencegahan HIV/AIDS, dukungan teman sesama WPS dan motivasi terhadap perilaku pencegahan penyakit HIV/AIDS WPS di Jakarta Timur tahun 2014. Desain penelitian secara cross sectional dengan pendekatan kuantitatif. Jumlah sampel dalam penelitian 60 responden yang diambil secara acak di wilayah Jatinegara - Jakarta Timur. Metode analisis menggunakan Structural Equation Model (SEM) menggunakan SmartPLS 2.0 dan SPSS 18. Hasil pengujian hipotesis ditemukan variabel yang berpengaruh langsung terhaadap perilaku pencegahan HIV/AIDS meliputi sikap dalam pencegahan HIV/AIDS dengan besarnya pengaruh 37,7\%, dukungan teman sesama WPS dengan besarnya pengaruh 22,9\%, motivasi dengan besarnya pengaruh 32,7\%, variabel sikap dan dukungan teman sesama WPS berpengaruh terhadap perilaku melalui motivasi dengan besarnya pengaruh masing-masing 5,6 \% dan 5,3\%. Terdapat $1 \%$ faktor lain yang berpengaruh terhadap perilaku pencegahan HIV/AIDS WPS yang tidak diteliti. Disarankan kepada pihak Puskesmas setempat dan LSM Bandungwangi untuk lebih memberikan pengertian dan pemahaman agar meningkatkan kesadaran sehingga memiliki sikap baik dalam pencegahan HIV/AIDS mengingat sikap merupakan faktor dominan yang berpengaruh terhadap perilaku.
\end{abstract}

Kata Kunci : : Sikap, Dukungan Teman, Motivasi

\begin{abstract}
HIV (Human Immunodeficiency Virus) is a virus that attacks the human immune system and weakens the body's ability to fight disease came. Someone being infected with HIV will cause the person suffering from AIDS (Acquired Immunodeficiency Virus). One of the groups at risk of contracting the disease are female sex workers (FSW) because of behavior that tend to be associated with many customers. The purpose of the study to determine the effect of direct and indirect as well as the amount of attitude in the prevention of HIV/AIDS, support fellow friends female seks workers (FSW) and motivation toward behavioral prevention of HIV/AIDS FSW in East Jakarta 2014. Cross-sectional study design with quantitative approach. The number of samples in the study 60 respondents drawn randomly Jatinegara region. The method of analysis using the Structural Equation Model (SEM) using SmartPLS 2.0 and SPSS 18. The results of hypothesis testing found of variables that directly affect the behavior of HIV/AIDS include attitudes in the prevention of HIV/AIDS with the influence of $37.7 \%$, support fellow friends FSW with the influence of $22.9 \%$, motivated by the influence of $32.7 \%$, variable attitude and support fellow FSW effect on behavior through motivation with the magnitude of the effect of each $5.6 \%$ and $5.3 \%$. There is a $1 \%$ other factors that influence the behavior of HIV/AIDS prevention FSW is not examined. It is suggested to the local health center and Bandungwangi NGOs to better provide insight and understanding in order to raise awareness so that it has a good attitude in the prevention of HIV/AIDS that attitude is the dominant factor influencing behavior.
\end{abstract}

Keywords

: Attitude, Support Friends, Motivation 


\section{Pendahuluan}

HIV (Human Immuno Deficiency Virus) merupakan virus yang menyerang sistem kekebalan tubuh manusia dan kemudian menimbulkan AIDS. Jadi, AIDS adalah kumpulan penyakit yang disebabkan oleh virus HIV yang merusak sistem kekebalan tubuh manusia, sehingga tubuh mudah diserang penyakit lain yang dapat berakibat fatal bah`kan kematian. Penyakit ini berjalan dengan lambat karena gejala AIDS baru dapat terlihat atau timbul kurang lebih 10 tahun setelah terinfeksi bahkan bisa lebih lama lagi. Tahun 2007, menurut data yang dikumpulkan oleh Amerika bersama program HIV/AIDS, 33 juta orang hidup dengan infeksi HIV, hampir 3 juta orang menjadi terinfeksi HIV dan 2 juta orang meninggal. Kasus HIV/AIDS di Indonesia dilaporkan pertama kali pada tahun 1987 di Bali, dan sampai akhir tahun 2003 jumlah kasus yang dilaporkan sebanyak 4.091. Jumlah kasus terbanyak yang dilaporkan dari DKI Jakarta, disusul Papua, Jawa Timur, Riau (Batam) dan Bali. ${ }^{1}$

Indonesia merupakan salah satu negara berkembang di wilayah Asia yang telah digolongkan menjadi negara dengan tingkat epidemi yang terkonsentrasi atau concentrade level epidemic (CLE) karena memiliki kantongkantong epidemi dengan prevalensi lebih dari 5\% pada subpopulasi beresiko seperti: pekerja seks komersial, narapidana, pengguna jarum suntik, donor darah, dan ibu hamil. Peningkatan prevalensi jumlah HIV berbanding lurus dengan jumlah CLE di suatu wilayah. Ini terbukti dari tiga besar provinsi dengan penderita HIV yaitu Jawa Barat sejumlah 3.233 orang, Jawa Timur 3.133 orang, DKI Jakarta 2.811 orang, juga terdapat peningkatan pada kelompok-kelompok beresiko HIV. ${ }^{2}$ Kasus pertama AIDS di Indonesia ditemukan tahun 1987. Antara tahun 1987 dan 1997, peningkatan infeksi tampak lambat, upaya penanggulangan pun sangat terbatas dan terfokus di sektor kesehatan. Pada pertengahan tahun 1990an, tampak peningkatan yang tajam dalam penularan di kalangan pengguna napza suntik (penasun). Pada tahun 1993 di kalangan penasun hanya 1 orang yang ditemukan HIV positif (di Jakarta), pada bulan Maret 2002 sudah dilaporkan 116 kasus AIDS karena penggunaan napza suntik di 6 provinsi. Pada akhir tahun 2004 dilaporkan 2.682 orang dengan AIDS dari 25 provinsi (kumulatif), diantaranya: 1844 adalah ODHA baru: 649 orang stadium HIV dan 1.195 AIDS baru. Sebanyak 824 orang $(68,95 \%$ dari AIDS yang baru dilaporkan) adalah akibat penggunaan napza suntik. Pada tahun yang sama, selain di kalangan penasun, di kalangan orang yang berisiko terinfeksi HIV akibat gaya hidup atau pekerjaannya: pekerja seks perempuan, laki-laki dan waria, laki-laki yang seks dengan laki-laki (LSL), dan pasangan masing-masing, semua juga menunjukkan peningkatan HIV secara signifikan. Antara tahun 2003 dan 2004 jumlah infeksi baru HIV dan kasus AIDS yang dilaporkan meningkat hampir 4 kali lipat $(3,81$ kali) antara lain karena meningkatnya sarana testing dan konseling, kemampuan mendiagnosa dan pelaporan yang lebih baik, terutama di Jawa, Bali dan beberapa provinsi lain di luar Jawa. Cara penularan pada bulan Juni 2006 dilaporkan oleh Kemenkes, bahwa 54,4\% dari kasus AIDS yang baru terjadi di kalangan penasun karena penularan melalui alat suntik, sedangkan bulan Juni 2011 angka tersebut sudah turun jadi $16,3 \%$. Sebaliknya, dalam kurun waktu yang sama, penularan heteroseksual meningkat dari $38,5 \%$ menjadi $76,3 \%$. Akibat dari makin meningkatnya penularan melalui hubungan seks berbeda jenis (heteroseksual) ini adalah: makin meningkatnya jumlah perempuan dan bayi yang dilaporkan sebagai kasus AIDS yang baru: Juni 2006 persentase kasus AIDS baru pada perempuan adalah 16,9\%, tahun 2011 menjadi $35,1 \%$, sedangkan penularan perinatal (dari ibu ke bayi) meningkat dari $2,16 \%$ menjadi $4,7 \% .^{3}$

Para ahli epidemiologi Indonesia dalam kajiannya tentang kecenderungan epidemi HIV dan AIDS memperkirakan bila tidak ada peningkatan upaya penanggulangan yang berarti, maka pada tahun 2010 jumlah kasus AIDS menjadi 400.000 orang dengan kematian 100.000 orang dan pada tahun 2015 menjadi 1.000.000 orang dengan kematian 350.000 orang. Penularan dari sub-populasi berprilaku beresiko kepada isteri atau pasangannya akan terus berlanjut. Diperkirakan pada akhir tahun 2015 akan terjadi penularan HIV secara komulatif pada lebih dari 38,500 anak yang dilahirkan dari ibu yang sudah terinfeksi HIV. ${ }^{1}$ Peraturan Presiden No. 75 Tahun 2006 mengamanatkan perlunya peningkatan upaya penanggulangan HIV dan AIDS di seluruh Indonesia. Respons harus ditunjukan untuk mengurangi semaksimal mungkin peningkatan kasus baru dan kematian. Transmisi HIV masuk kedalam tubuh manusia melalui 3 cara, yaitu 
secara vertikal dari ibu yang terinfeksi HIV ke anak, secara transeksual (homoseksual maupun heteroseksual) dan secara horizontal yaitu kontak darah atau produk darah yang terinfeksi. Kontak seksual merupakan salah satu cara utama transmisi HIV di berbagai belahan dunia. Virus ini dapat ditemukan dalam cairan semen, cairan vagina, cairan servik. Virus akan terkonsentrasi dalam cairan semen, terutama bila terjadi peningkatan jumlah limfosit dalam cairan, seperti pada keadaan peradangan genetalia misalnya uretritis, epididimitis, dan kelainan lain yang berhubungan dengan penyakit menular seksual. Hubungan seksual lewat anus adalah merupakan transmisi infeksi HIV yang lebih mudah karena pada anus hanya terdapat membran mukosa rektum yang tipis dan mudah robek, sehingga anus mudah terjadi lesi, bila terjadi lesi maka akan memudahkan masuknya virus sehingga memudahkan untuk terjadinya infeksi. ${ }^{1}$

Temuan kasus IMS termasuk HIV/AIDS sebenarnya tidak akan terjadi jika PSK dan pelanggannya mamiliki perilaku yang sehat. Perilaku yang sehat adalah menggunakan kondom dan melakukan pemeriksaan rutin ke pelayanan kesehatan dan tidak menggunakan jarum suntik bersama. ${ }^{4}$ Kasus AIDS merupakan fenomena gunung es, yg muncul kepermukaan sebagian kecil dari yang sebenarnya menurut WHO : 1 kasus HIV : tersembunyi 100 sampai dengan 200 orang. Laporan situasi perkembangan HIV/AIDS di Indonesia tahun $2013^{5}$ melaporkan sampai dengan bulan Septermber jumlah penyandang HIV mencapai 20.397 orang dan yang telah menjadi AIDS berjumlah 2.763 orang. Dari data tersebut, salah satu kelompok yang rentan tertular AIDS yaitu Wanita Pekerja Seks (WPS) sebanyak 4\%. Adapun jumlah akumulatif WPS yang mengalami AIDS tahun 1987 - 2013 berjumlah 1.771 orang. Sedangkan perilaku yang paling beresiko menularkan HIV/AIDS adalah perilaku heteroseksual sebanyak $78,4 \%$. Perilaku seksual meningkat tajam dikarenakan menjamurnya praktik prostitusi. Sedangkan jumlah HIV di DKI Jakarta sampai dengan September 2013 yaitu 27.224 orang. Oleh karena tingginya risiko terkena virus HIV di kalangan WPS dan supaya para WPS tersebut tidak sampai mengidap virus HIV dan menularkannya, maka yang perlu dilakukan adalah upaya pencegahan (preventive) HIV/AIDS. Berkaitan dengan pencegahan ada tiga cara yang dapat dilakukan untuk mencegah tertularnya HIV/AIDS yang meliputi tidak melakukan hubungan seksual sebelum menikah, tidak gonta-ganti pasangan, bagi yang memiliki perilaku seksual aktif hendaknya memiliki sedikit pasangan seksual dan menggunakan kondom saat melakukan hubungan seksual. ${ }^{2}$

Di DKI Jakarta penggunaan kondom pada PSK hanya 15\% ditahun 1996. Kondisi ini tidak banyak berubah setelah 9 tahun kemudian. Tahun 2004 penggunaan kondom masih relatif stabil yaitu 16\%. Selama rentang waktu 1996 hingga 2004 terjadi beberapa kali kenaikan dan penurunan. ${ }^{4}$

Tahun 2006, program pencegahan penularan melalui transmisi seksual dikenal sebagai "Program Penggunaan Kondom 100\%" (PPK 100\%) yang mengikuti "model" yang sangat sukses di Thailand. Didorong oleh WHO dan dukungan teknis berbagai mitra, pendekatan ini dikembangkan secara serius di Indonesia. Namun hasil IBBS 2002 dan 2007 menunjukkan, bahwa Program Penggunaan Kondom $100 \%$ di Indonesia tidak berhasil. Data menunjukkan, bahwa penggunaan kondom tetap rendah, Infeksi Menular Seksual (IMS) termasuk HIV tetap tinggi, bahkan makin meningkat di kalangan pekerja seks perempuan dan waria. Kegagalan tersebut disebabkan berbagai faktor yang sulit diatasi: pertama, keengganan para pelanggan untuk memakai kondom walaupun tersedia; kedua, ketersediaan kondom dan pelicin masih jauh dibawah kebutuhan; ketiga, pendapat masyarakat umum dan para pemimpin di sebagian daerah, seringkali negatif bahkan menentang pembahasan tentang penggunaan kondom apalagi terkait pelacuran. Disamping itu, pekerja seks yang diluar "lokalisasi" seperti pekerja seks jalanan (laki-laki, perempuan dan waria), pekerja seks yang bekerja di bar, karaoke, dan panti pijat, laki-laki yang seks dengan laki-laki, pada umumnya sulit mendapat informasi, kondom dan layanan kesehatan. ${ }^{3}$ Selain itu, kecenderungan WPS berhubungan dengan banyak pasangan atau gonta-ganti pasangan dan mode hubungan seksual yang rentan yaitu melalui mulut dan anus karena merupakan bagian yang mudah lecet bahkan dapat terjadi kerobekan pada anus karena selaputnya mudah robek dan kurangnya kesadaran untuk memanfaatkan pelayanan kesehatan yang ada. ${ }^{2}$ Kunci dalam pencegahan untuk kelompok beresiko diatas ditujukan untuk mengubah perilaku berisiko menjadi perilaku aman. 
Perilaku dapat dikatakan suatu kegiatan atau aktivitas yang dilakukan manusia jika dilihat dari sudut pandang biologis sehingga dapat diamati baik secara langssung maupun tidak langsung oleh orang lain. Karakteristik dan determinan perilaku individu akan mempengaruhi individu dalam memberikan respons atau reaksi terhadap stimulus yang diterima sehingga walaupun stimusnya sama akan menghasilkan respons atau reaksi yang berbeda pada setiap individu. Determinan perilaku dapat dibedakan mejadi dua macam, yaitu faktor internal dan faktor eksternal. Faktor internal merupakan karakteristik dari orang yang bersangkutan yang bersifat bawaan seperti ras, sifat fisik, sifat kepribadian (pemalu, pemarah dan penakut), bakat bawaan, tingkat kecerdasan dan jenis kelamin. Faktor eksternal meliputi lingkungan fisik, sosial, budaya, ekonomi dan politik. Faktor lingkungan sering merupakan faktor yang dominan terhadap perilaku seseorang. Perilaku merupakan totalitas penghayatan atau aktivitas seseorang yang merupakan hasil bersama atau resultan antara faktor internal dan eksternal. Perilaku manusia sangatlah kompleks dan mempunyai ruang lingkup yang sangat luas, Bloom membagi perilaku ke dalam tiga domain, yaitu 1) kognitif, 2) afektif, dan 3) psikomotor. Sehingga untuk mempermudah pengukuran perilaku dibagi menjadi tiga domain, diantaranya pengetahuan, sikap dan tindakan. Sedangkan perilaku kesehatan merupakan suatu respon seseorang terhadap stimulus atau objek yang berkaitan dengan sehat-sakit, penyakit, dan faktor-faktor yang mempengaruhi sehat-sakit (kesehatan) seperti makanan, minuman, lingkungan dan pelayanan kesehatan. Dengan perkataan lain perilaku kesehatan adalah semua aktivitas atau kegiatan seseorang, baik yang dapat diamati maupun yang tidak dapat diamati yang berkaitan dengan pemeliharaan dan peningkatan kesehatan. Pemeliharaan kesehatan ini menyangkut mencegah atau melindungi diri dari penyakit dan masalah kesehatan lain, meningkatkan kesehatan, dan mencari penyembuhan apabila sakit atau terkena masalah kesehatan. Perilaku sendiri dipengaruhi oleh faktor eksternal dan internal. Faktor eksternal atau stimulus adalah faktor lingkungan, baik lingkungan fisik, maupun non fisik dalam bentuk sosial, budaya, ekonomi, politik dan sebagainya. Dari penelitian-penelitian yang ada faktor eksternal yang paling besar perannya dalam membentuk perilaku manusia adalah faktor sosial dan budaya dimana seseorang tersebut berada. Sedangkan faktor internal yang menentukan seseorang itu merespons stimulus dari luar adalah: perhatian, pengamatan, persepsi, motivasi, fantasi, sugesti dan sebagainya salah satunya adalah sikap karena sikap merupakan bagian dari karakteristik individu. Faktor sosial sebagai faktor eksternal yang mempengaruhi perilaku antara lain, struktur sosial, pranata-pranata sosial dan permasalahan-permasalahan sosial yang lain. Faktor budaya sebagai faktor eksternal yang mempengaruhi perilaku seseorang antara lain: nilai-nilai, adat istiadat, kepercayaan, kebiasaan masyarakat, tradisi dan sebagainya. Sedangkan faktor - faktor internal yang mempengaruhi terbentuknya perilaku seperti perhatian, motivasi, persepsi, inteligensi, fantasi dan sebagiannya. Sedangkan perilaku hidup sehat merupakan perilaku yang berkaitan dengan upaya atau kegiatan seseorang untuk mempertahankan dan meningkatkan kesehatannya yang mencakup makan dan menu seimbang (appropriate diet), olahraga teratur, tidak merokok, tidak minum-minuman keras dan narkoba, istirahat yang cukup, mengendalikan stress, perilaku atau gaya hidup lain yang positif bagi kesehatan, misalnya tidak berganti-ganti pasangan seksual. ${ }^{6}$ Timbulnya kesadaran yang baik untuk konsisten dalam pemakaian kondom didasari oleh adanya kemauan, motivasi dan pengetahuan yang cukup sehingga WPS mampu melakukan tindakan untuk menjaga kesehatan reproduksinya. Sehingga indikator pencegahan HIV/AIDS WPS dalam penelitian ini meliputi menggunakan kondom, memilih pelanggan, dan menggunakan fasilitas pelayanan kesehatan.

Teori Tindakan Beralasan (theory of reasoned action) menjelaskan bahwa sikap mempengaruhi perilaku lewat suatu proses pengambilan keputusan yang teliti dan beralasan dan dampaknya sehingga teori perilaku beralasan diperluas menjadi Teori Perilaku Terencana (theory of planned behavior). Kedua teori tersebut menyebutkan bahwa sikap didasari oleh adanya keyakinan terhadap suatu perilaku. Inti teori ini mencakup 3 hal yaitu; yaitu keyakinan tentang kemungkinan hasil dan evaluasi dari perilaku tersebut (behavioral beliefs), keyakinan tentang norma yang diharapkan dan motivasi untuk memenuhi harapan tersebut (normative beliefs), serta keyakinan tentang adanya faktor yang dapat 
mendukung atau menghalangi perilaku dan kesadaran akan kekuatan faktor tersebut (control beliefs). ${ }^{7}$ Pembentukan sikap seseorang sangat ditentukan oleh: kepribadian, intelegensia, minat. Sikap dapat dipelajari, dibentuk, dan sikap akan mencerminkan kepribadian seseorang. Sikap dapat dipelajari, dimana belajar itu adalah berlatih, dan belajar berlangsung seumur hidup. ${ }^{6}$ Sehingga indikator sikap dalam penelitian meliputi sikap dalam menggunakan kondom, sikap dalam memilih pelanggan dan sikap dalam menggunakan fasilitias pelayanan kesehatan. Sedangkan indikator motivasi meliputi kebutuhan, tujuan, dan insentif.

Hasil analisis ${ }^{8}$ menjelaskan dengan adanya stigma yang kurang baik terhadap pekerjaan mereka dapat menghambat motivasi dalam memanfaatkan pelayanan kesehatan. Kemampuan WPS untuk dapat memilih pelanggan yang mau mengikuti aturan untuk mencegah penularan HIV/AIDS juga merupakan salah satu cara yang bisa dilakukan WPS untuk menjaga kesehatan reproduksinya. Selain itu, ada dan tidaknya dukungan sosial berkaitan dengan upaya dalam menjaga dan meningkatkan kesehatan reproduksi WPS. Sumber dukungan sosial yang berperan bagi WPS untuk konsistensi pemakaian kondom dan pemanfaatan pelayanan kesehatan adalah dukungan dari tenaga kesehatan, pengelola, teman sebaya dan LSM sehingga dapat memotivasi WPS untuk melakukan pencegahan penularan HIV/AIDS. Penelitian yang dilakukan Green \& Kreuter yang mengatakan dukungan dari pengelola dan teman sebaya merupakan sumber utama bagi WPS untuk konsisten memakai kondom. Jenis dukungan yang dapat diberikan $^{10}$ meliputi dukungan emosional, penghargaan, informatif dan instrumental. Dukungan teman sesama WPS dalam penelitian ini meliputi dukungan informasi kesehatan, dukungan emosional, dan dukungan instrumental.

Berdasarkan hasil survei cepat perilaku (SCP), ditemukan bahwa sebanyak 91\% dari total WPS telah terpapar informasi mengenai cara menggunakan kondom dengan alat peraga/dildo, namun sebanyak $21 \%$ WPS masih menerima injeksi pencegahan IMS di luar layanan kesehatan (mantri keliling) dan $44 \%$ meminum antibiotik yang dibeli tanpa resep sehingga dapat disimpulkan bahwa pemanfaatan layanan kesehatan untuk pengobatan IMS masih belum optimal begitupun dengan pencegahan
HIV/AIDS. Dalam hal perilaku penggunaan kondom pada hubungan seks terakhir, ditemukan bahwa 91\% WPS menyatakan bahwa kondom tersedia, sebanyak $83 \%$ menawarkan untuk menggunakan kondom dan $74 \%$ menggunakan kondom. Namun pada hubungan seks 1 minggu terakhir, angka tersebut menurun menjadi 66\% WPS menawarkan kondom dan baru 41\% WPS secara konsisten menggunakan kondom. Kecenderungan WPS berhubungan dengan banyak pasangan atau gonta-ganti pasangan dan mode hubungan seksual yang rentan merupakan salah satu yang dapat meningkatkan angka HIV/AIDS. ${ }^{11}$ Hasil penelitian lain $^{12}$ terdapat $13,3 \%$ WPS yang kurang mempunyai motivasi untuk melakukan VCT (menggunakan pelayanan kesehatan). Artinya, bahwa walaupun adanya perhatian, kondom yang diberikan secara gratis dan informasi tentang HIV/AIDS (berkaitan dengan pencegahan) sudah diterima namun jika tidak ada dorongan baik dari dalam maupun dari luar yang memotivasi WPS maka perilaku pencegahan HIV/AIDS tidak akan terwujud. Hasil studi crros sectonal ${ }^{2}$ menggambarkan adanya hubungan antara dukungan sosial dengan peningkatan kualitas hidup PSK termasuk ODHA. Dukungan sosial diartikan sebagai derajat kebutuhan dasar individu akan afeksi, persetujuan, kepemilikan dan keamanan didapat lewat interaksi dengan orang lain.

Berdasarkan studi pendahuluan yang telah dilakukan, data yang terdapat di LSM dalam tahun 2011-2013 terdapat 20\% WPS yang secara rutin menggunakan kondom secara rutin dan $60 \%$ tergantung pelanggan, terdapat $30 \%$ dari jangkauan yang memilih pelanggan padahal terdapat 90\% WPS mengetahui tentang HIV/AIDS dan $60 \%$ merasa takut tertular HIV/AIDS namun baru 327 WPS yang melakukan test HIV (VCT). Para WPS banyak mendapat dukungan dari teman satu rumah/bekerja, pasangan tetap/pacar dan teman sekitar lokasi dalam pencegahan HIV/AIDS karena sering diadakan pula kegiatan bersama di LSM sehingga para WPS mendapat banyak dukungan. Jumlah WPS yang sampai saat ini terjangkau di LSM berjumlah 2500, dari jumlah tersebut selama tahun 2011-2013 terdapat 10 orang ODHA yang telah meninggal dan 8 orang yang masih hidup dengan HIV/AIDS sehingga beresiko menularkan pada pelanggan maupun WPS lain karena sering gonta-ganti pasangan 
bahkan dapat menulari wanita dan anak yang dilahirkan.

Penelitian ini bertujuan untuk mengetahui pengaruh langsung dan tidak langsung serta besaran sikap dalam pencegahan HIV/AIDS, dukungan teman sesama wanita pekerja seks (WPS) dan motivasi terhadap perilaku pencegahan penyakit HIV/AIDS WPS di Jakarta Timur tahun 2014.

\section{Metode}

Penelitian ini dilakukan secara kuantitatif dengan pendekatan cross sectional yang dilaksanakan di Jakarta Timur khususnya diwilayah Jatinegara yang merupakan daerah jangkauan LSM Bandungwangi yang dilaksanakan bulan Februari 2014. Populasi merupakan WPS yang terdaftar pada program pendampingan Bandungwangi di Jakarta Timur sebanyak 2500 dengan jumlah sampel 60 responden yang didapat dari jumlah indikator dikali $\operatorname{lima}^{13}$ yang memiliki kriteria inklusi WPS yang terdaftar dalam program pendampingan Bandungwangi di Jakarta Timur, masih aktif menjadi WPS dan bersedia menjadi responden penelitian. Sedangkan kriteria eksklusi merupakan subyek penelitian yang tidak dapat mewakili sampel penelitian karena tidak memenuhi syarat penelitian, yaitu berhalangan hadir sehingga tidak dapat dijadikan sebagai sampel.

Skala pengukuran dalam penelitian ini ada dua yang mana untuk variabel sikap dan motivasi menggunakan skala Likert yang kemudian dikonversi kedalam nilai 1 sampai dengan 5 sedangkan untuk variabel perilaku dan dukungan berbentuk sematik differensial yang dikembangkan oleh Osgood yang memiliki 5 point. Pada skala ini jawaban "sangat positifnya" berada paling kanan garis dan jawaban "sangat negatifnya" berada paling kiri garis, atau sebaliknya. Data yang diperoleh adatah data interval. Responden yang memilih angka 5 berarti nilainya sangat positif, sedangkan jika memilih angka 3 berarti nilainya netral, dan bila memilih angka 1 berarti nilinya sangat negatif. ${ }^{14}$

Data primer yang digunakan dalam penelitian ini melalui alat bantu (instrument) berarti angket/pertanyaan diperoleh melalui penyebaran kuosioner yang berisi 4 variabel dengan 12 indikator yang mana setiap indikator mengandung 5 pernyataan sehingga total keseluruhan pernyataan dalam kuosioner berjumlah 60. Sedangkan data sekunder diperoleh dari laporan LSM Bandungwangi.

Sebelum melakukan penelitian, setiap responden di informasikan tujuan dari penelitian dan dijelaskan bahwa keterangan yang diberikan oleh responden akan dirahasiakan serta responden boleh menolak jika tidak bersedia menjadi responden dan bila bersedia menjadi responden maka penulis akan memberikan kuosioner penelitian.

Uji validitas dan reliabilitas dilakukan untuk mengetahui apakah instrumen yang digunakan untuk penelitian telah dapat mengukur apa yang harus diukur dan sejauh mana instrumen yang digunakan dipercaya untuk penelitian. Uji validitas dan reliabilitas pada butir instrumen penelitian menggunakan SPSS sebelum disebar untuk penelitian. Sedangkan uji validitas dan reliabilitas variabel endogen dan eksogen menggunakan PLS. Loading faktor menurut beberapa ahli berbeda-beda dan secara longgar disarankan diatas 0,4 dan secara ketat diatas 0,7. Sedangkan nilai composite reability mengukur internal consistency dan nilainya harus diatas 0,60 nilai average variance extracted (AVE) harus diatas $0,5 .^{13}$

Kuosioner dalam penelitian ini telah diujikan terlebih dahulu pada wanita pekerja seks berjumlah 20 orang. Dengan jumlah sampel 20 orang, $\mathrm{df}=18$ maka didapatkan $\mathrm{r}$ tabelnya 0,38 . Jika $r$ hitung lebih besar dari $r$ tabel dinyatakan valid, sedangkan reliabilitas dapat dilihat pada kolom Cronbach's Alpha if Item Deleted, jika nilainya $>0,7$ maka dinyatakan reliabel.

Dalam penelitian ini analisis data menggunakan pendekatan PLS dengan menggunakan software smartPLS. PLS adalah model persamaan menggunakan persamaan SEM (Structural Equation Models) atau model persamaan struktural, yaitu sebuah model statistik yang memberikan perkiraan perhitungan dari kekuatan hubungan hipotesis antar variabel dalam sebuah model teoritis baik secara langsung atau melalui variabel antara (intervening or mediating variables). Model 
hubungan semua variabel laten dalam PLS terdiri dari tiga ukuran, yaitu ${ }^{13}$ :

1. Inner model yang menspesifikasi hubungan antar variabel laten (structural model) yang menggambarkan hubungan antar variabel laten berdasarkan pada substansive theory.

2. Outer model sering juga disebut outer relation yang mendefinisikan bagaimana setiap blok indikator bagaimana berhubungan dengan variabel latennya.

Data yang disajikan pada awal hasil analisa berupa gambaran mengenai sampel, dimana terdapat tabel yang disertai penjelasan untuk membantu pembaca mengenal karakteristik responden. Hasil analisa SEM dari pengolahan data output yang menggunakan SmartPLS 2.0 disajikan dalam bentuk tabel dan lain-lain. Penyajian yang lebih lengkap akan dilampirkan. Sedangkan pengujian hipotesis berdasarkan dari keluaran hasil pengolahan data.

\section{Hasil}

Sebagian besar dari 60 wanita pekerja seks (WPS) berumur 15-20 tahun (41,7\%), memiliki status belum menikah $(63,3 \%)$, pendidikan tamat Sekolah Dasar $(46,7 \%)$ dan telah menjadi WPS selama 1-3 tahun (36,7\%). Deskripsi jawaban dari 60 WPS sebagian besar berada direntang aktual 41-46 (30\%) pada variabel perilaku pencegahan HIV/AIDS, $42-48 \quad(31,7 \%)$ pada variabel motivasi, $39-44$ (25\%) pada variabel dukungan teman sesama WPS, 48-54 $(28,2 \%)$ pada variabel sikap dalam pencegahan HIV/AIDS.

Variabel perilaku pencegahan HIV/AIDS memiliki kisaran jawaban responden antara 29-70 mendekati rentang teoritis (15-75) dengan rata-rata 44,08 dan standar deviasi 10,848. Variabel motivasi memiliki kisaran jawaban responden antara 28-70 mendekati rentang teoritis (15-75) dengan rata-rata 43,98 dan standar deviasi 10,598. Variabel dukungan teman sesama WPS memiliki kisaran jawaban responden antara 27-67 mendekati rentang teoritis (1575) dengan rata-rata 44,05 dan standar deviasi 10,366. Variabel sikap dalam pencegahan HIV/AIDS memiliki kisaran jawaban responden antara 27-71 mendekati rentang teoritis (15-75) dengan rata-rata 44,15 dan standar deviasi 10,804.

Hasil uji Chi-square, variasi karakteristik responden tidak ada yang berhubungan dengan jawaban atas pertanyaan dari perilaku pencegahan HIV/AIDS, motivasi, dukungan teman sesama WPS dan sikap dalam pencegahan HIV/AIDS karena $P_{\text {value }}>0,05$.

Berdasarkan gambar 1 dapat dijelaskan bahwa nilai loading factors semuanya telah memenuhi persyaratan yaitu lebih besar dari 0,5 . konstruk. Sehingga dapat dikatakan penelitianini memiliki tingkat validitas dan realibilitas yang baik.

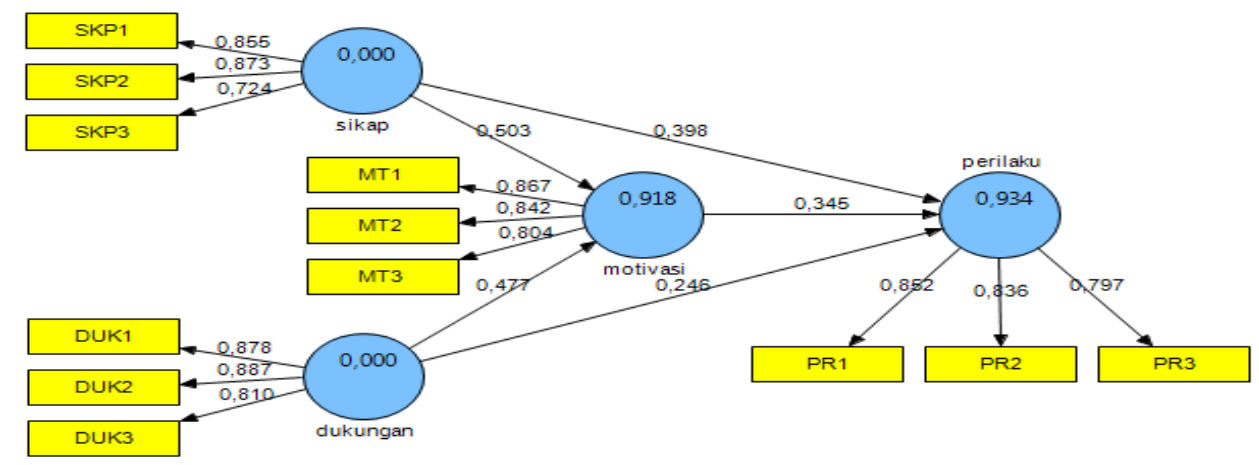

Gambar 1. Output PLS (Loading Factors)

Sumber: Hasil olah PLS, 2014 


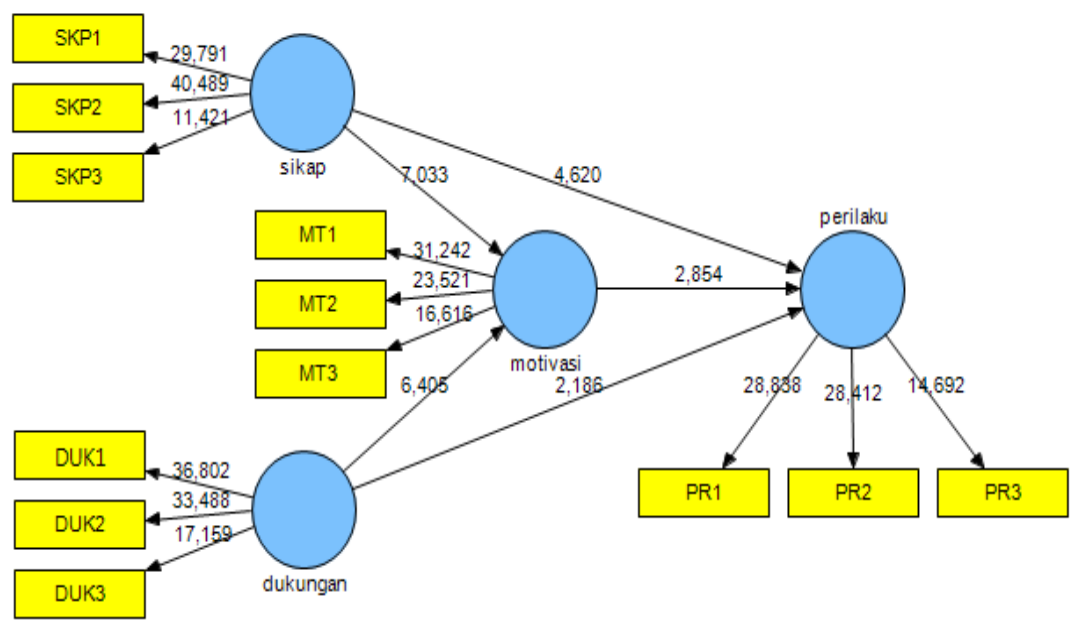

Gambar 2. Output PLS (Uji Statistik)

Sumber: Hasil olah PLS, 2014

Tabel 1. Besaran Pengaruh Langsung dan Tidak Langsung Sikap dalam Pencegahan HIV/AIDS, Dukungan Teman sesama Wanita Pekerja Seks (WPS) dan Motivasi terhadap Perilaku Pencegahan HIV/AIDS WPS Di Jakarta Timur Tahun 2014

\begin{tabular}{|c|c|c|c|c|c|c|c|}
\hline Variabel & $\mathbf{L V}$ & $\begin{array}{c}\text { Direct } \\
\text { Rho }\end{array}$ & $\begin{array}{c}\text { Indirect } \\
\text { Rho }\end{array}$ & Total & \% Direct & $\begin{array}{c}\% \\
\text { Indirect }\end{array}$ & Total \\
\hline $\begin{array}{c}\text { Dukungan } \\
\text { Teman }\end{array}$ & 0,932618 & 0,246 & 0,164 & 0,410 & 22,95 & 5,37 & 28,32 \\
\hline Sikap & 0,946793 & 0,398 & 0,173 & 0,571 & 37,71 & 5,66 & 43,37 \\
\hline Motivasi & 0,949328 & 0,345 & - & 0,345 & 32,77 & - & - \\
\hline \multicolumn{4}{|c|}{ Total } & 1,326 & 93,43 & 11,03 & 71,69 \\
\hline
\end{tabular}

Sumber: Hasil olah PLS, 2014

Sedangkan nilai akar $A V E$ telah lebih besar dari pada nilai korelasi antar variabel laten dengan nilai $>0,8$ dan nilaicomposite realibility $>0,8$ dimana standaryangditetapkan $>0,7$ serta uji reabilitas yang diperkuat dengan cronbach alpha didapat $>0,7$ dimana nilai yang diharapkan $>0,6$ untuk semua konstruk.

Gambar 2 menunjukan bahwa besar nilai $\mathrm{t}$ statistik dari sikap dalam pencegahan HIV/AIDS, dukungan teman sesama WPS dan motivasi terhadap perilaku pencegahan HIV/AIDS >1,96.Nilai R-Square menjelaskan pengaruh langsung dan tidak langsung variabel sikap dalam pencegahan HIV/AIDS, dukungan teman sesama WPS dan motivasi terhadap perilaku pencegahan
HIV/AIDS sebesar $93,44 \%$ dan $6,56 \%$ dipengaruhi oleh faktor lain yang tidak diteliti. Sedangkan pengaruh motivasi ditentukan oleh sikap dalam pencegahan HIV/AIDS dan dukungan teman sesama WPS secara langsung sebesar 91,83\% dan $8,17 \%$ dipengaruhi faktor lain yang tidak diteliti. Sedangkan besar pengaruh tidak langsung sikap dalam pencegahan HIV/AIDS dan dukungan teman sesama WPS terhadap perilaku pencegahan HIV/AIDS melalui motivasi sebesar 11,03\%. (tabel 1)

Persamaan matematika yang sesuai dengan analisis diatas, yaitu:

$$
\begin{array}{ll}
\eta_{1} & =y_{2} \xi_{1}+y_{3} \xi_{2}+\zeta_{1} \\
\text { Motivasi } & =0,503 * \text { sikap dalam pencegahan HIV/AIDS }
\end{array}
$$




$$
+0,477 *_{\text {dukungan teman sesama WPS }}+
$$$$
0,286^{*} \text { faktor lain }
$$

Kesimpulannya, motivasi akan meningkat 0,348 jika terdapat satu kali intervensi pada sikap dalam pencegahan HIV/AIDS, dukungan teman sesama WPS dan faktor lain.

$$
\begin{aligned}
\eta_{2} & =y_{1} \xi_{1}+y_{4} \xi_{2}+\beta \eta_{1}+\zeta_{2} \\
\text { Perilaku }= & 0,398^{*} \text { sikap dalam pencegahan HIV/AIDS } \\
& +0,246^{*} \text { dukungan teman sesama WPS }+ \\
& 0,346+0,256^{*} \text { faktor lain }
\end{aligned}
$$

Maka, perilaku pencegahan HIV/AIDS akan meingkat sebesar 0,312 apabila terdapat satu kali intervensi pada sikap dalam pencegahan HIV/AIDS, dukungan teman sesama WPS, motivasi dan faktor lain yang tidak diteliti.

Sedangkan Predictive Relavance (Nilai

$$
Q \text { Square) }
$$

$$
\begin{aligned}
Q^{2} & =1-\left(1-\mathrm{R}_{1}{ }^{2}\right)\left(1-\mathrm{R}_{2}{ }^{2}\right) \\
& =1-(1-0,918339)(1-0,934470) \\
& =0,99
\end{aligned}
$$

Galat Model= $1 \%$

Hal ini menunjukan bahwa model hasil analisis dapat menjelaskan $99 \%$ keragaman data dan mampu mengkaji fenomena yang dipakai dalam penelitian, sedangkan $1 \%$ merupakan komponen atau faktor lain yang tidak ada dalam penelitian ini.

\section{Pembahasan}

Sikap dalam Pencegahan HIV/AIDS $\left(\xi_{1}\right)$ Berpengaruh Langsung terhadap Perilaku Pencegahan HIV/AIDS WPS (n $\left.\mathbf{n}_{2}\right)$

Sikap dalam pencegahan HIV/AIDS berpengaruh secara signifikan terhadap perilaku pencegahan HIV/AIDS. Dalam penelitian ini sikap diartikan sebagai penilaian wanita pekerja seks (WPS) dalam mencegah penyakit HIV/AIDS yang melibatkan pikiran, perasaan dan pendapat tentang penyakit HIV/AIDS yang meliputi sikap dalam penggunaan kondom, sikap dalam memilih pelanggan dan sikap dalam menggunakan pelayanan kesehatan.

Berdasarkan uji statistik dengan menggunakan PLS diperoleh koefisien parameter 0,398 , t statistik 4,619>1,96 pada CI 95\% sehingga dapat disimpulkan bahwa sikap dalam mencegah HIV/AIDS berpengaruh positif dan signifikan terhadap perilaku pencegahan HIV/AIDS WPS dengan besarnya pengaruh $37,71 \%$. Selain itu, diketahui bahwa indikator sikap dalam memilih pelanggan memiliki tingkat signifikan paling tinggi diantara yang lainnya sehingga apabila WPS hanya melayani pelanggan yang mau mengikuti aturan (menggunakan kondom), hanya memiliki pelanggan tetap (tidak gontaganti pasangan) dapat mengurangi resiko tertular HIV/AIDS.

Hasil penelitian ini sesuai dengan penelitian ${ }^{15}$ yaitu semua pekerja seks komersil (PSK) beranggapan bahwa dengan menggunakan alat kontrasepsi (kondom) akan terhindar dari penyakit menular seksual termasuk HIV/AIDS. Sikap setuju dalam memilih pelanggan dapat mencegah penula 7 HIV/AIDS memiliki tingkat signifikan pal tinggi artinya WPS menyadari bahwa pekerjaannya beresiko tinggi tertular HIV/AIDS sehingga menyetujui bahwa dengan membujuk atau bernegosiasi dengan pelanggan agar mau menggunakan kondom kemudian konsisten hanya melayani pelanggan tertentu atau yang tidak membahayakan bagi dirinya. Dengan demikian, pekerja seks dapat menentukan pilihan terbaik untuk dirinya sendiri dalam menentukan pelanggan yang akan dilayaninya untuk mengurangi risiko penularan HIV/AIDS. Karena sehat merupakan hak semua orang termasuk WPS.

Sikap setuju dalam penggunaan pelayanan kesehatan membuktikan bahwa WPS ditempat penelitian telah menyadari keuntungan dalam menggunakan pelayanan kesehatan. Menurut teori ${ }^{2}$, upaya petugas kesehatan untuk menanggulangi Penyakit Menular Seksual (PMS) termasuk HIV/AIDS, dapat dilakukan melalui tiga tingkat pencegahan, yaitu salah satunya dengan menggunakan upaya pencegahan primer, berupa kegiatan promotif dan preventif yaitu kampanye penggunaan kondom bagi subpopulasi seksual aktif, dan screaning pada subpopulasi resiko tinggi. Oleh karena sikap merupakan kesiapan atau kesediaan untuk bertindak, dengan demikian, sikap belum merupakan suatu tindakan atau aktifitas, akan tetapi merupakan predisposisi tindakan suatu perilaku sehingga dapat mempengaruhi perilaku individu dan dalam menentukan sikap yang utuh, pengetahuan, pikiran, keyakinan, dan emosi memegang peranan penting.

Dukungan Teman Sesama WPS $\left(\xi_{2}\right)$ Berpengaruh Langsung terhadap Perilaku Pencegahan HIV/AIDS WPS $\left(\mathbf{n}_{2}\right)$

Dukungan dapat diperoleh dari berbagai sumber salah satunya adalah teman. Penelitian menekankan dukungan dari teman sesama 
WPS yang meliputi dukungan informasi khususnya berkaitan dengan kesehatan, dukungan emosional dan dukungan instrumental.

Berdasarkan uji statistik dengan menggunakan PLS diperoleh koefisien parameter 0,2461 , t statistik $2,1856>1,96$ pada CI 95\% sehingga dapat disimpulkan bahwa dukungan dari teman sesama WPS berpengaruh positif dan signifikan terhadap perilaku pencegahan HIV/AIDS WPS dengan besarnya pengaruh 22,95\%. Sedangkan indikator yang memiliki signifikan tinggi y dukungan informasi kesehatan dan emosior

Menurut penelitian ${ }^{15}$,pekerja sекs komersial mendapat dukungan dari teman sejawat untuk melakukan pencegahan HIV/AIDS dengan selalu diingatkan tentang jadwal Voluntary Counselling and Testing (VCT), saling memberi saran, saling menegur, dan saling mendukung. Selain itu hasil penelitian lain $^{17}$ menjelaskan bahwa teman berpengaruh terhadap perilaku karena berdasarkan hasil penelitiannya diketahui bahwa responden yang memiliki pengetahuan baik berkaitan dengan VCT karena mendapat informasi dari teman yang memiliki pekerjaan sama, begitupun sebaliknya responden yang memiliki pengetahuan rendah dikarenakan tidak pernah mendapat informasi dari teman maupun dari orang lain tentang manfaat VCT.

Hasil penelitian juga sesuai dengan teori Snehandu Kar Model ${ }^{6}$ dimana salah satu faktor yang berpengaruh terhadap perilaku adalah dukungan sosial (teman) karena WPS sendiri memiliki kecendurungan menutup diri, namun lebih terbuka dengan lingkungan dalamnya, khususnya sesama WPS.

\section{Motivasi $\left(\eta_{1}\right)$ Berpengaruh Langsung terhadap Perilaku Pencegahan HIV/AIDS $\operatorname{WPS}\left(\mathbf{n}_{2}\right)$}

Setiap individu memiliki kondisi internal, dimana kondisi tersebut turut berperan dalam aktifitas dirinya sehari- hari. Salah satu dari kondisi internal tersebut adalah motivasi. Motivasi adalah dorongan dasar yang berasal dari dalam maupun dari luar yang menggerakkan seseorang bertingkah laku. Oleh, karena itu, perbuatan seseorang yang didasarkan atas motivasi tertentu mengandung tema sesuai dengan motivasi yang mendasarinya. ${ }^{18}$ Motivasi dalam penelitian ini meliputi kebutuhan, tujuan dan insentif.
Berdasarkan uji statistik dengan menggunakan PLS diperoleh koefisien parameter $0,3452 \mathrm{t}$ statistik 2,8537 >1,96 pada CI 95\% sehingga dapat disimpulkan bahwa motivasi berpengaruh positif dan signifikan terhadap perilaku pencegahan HIV/AIDS WPS dengan besarnya pengaruh $32,77 \%$. Adapun indikator yang memiliki tingkat signifikan paling tinggi adalah kebutuhan disusul tujuan.

Hasil ini sesuai dengan penelitian yang dilakukan sebelumnya ${ }^{15}$ didapatkan motivasi WPS mengikuti tes Voluntary Counselling and Testing (VCT) adalah karena keingintahuan akan hasil tes. Hasil penelitian mengenai imbalan yang di dapatkan Pekerja Seks Komersial (PSK) setelah melakukan Voluntary Counselling and Testing (VCT) akan mendapat alat kontrasepsi (kondom). Program layanan Voluntary Counseling and Testing (VCT) sendiri dimaksudkan membantu masyarakat terutama populasi berisiko dan anggota keluarganya untuk mengetahui status kesehatan yang berkaitan dengan HIV, dimana hasilnya dapat digunakan sebagai bahan motivasi dalam upaya pencegahan HIV. Hal ini sesuai dengan teori ${ }^{2}$ bahwa upaya pencegahan meluasnya penyakit HIV/ AIDS salah satunya dengan mengikuti tes Voluntary Counselling and Testing (VCT).

Kebutuhan timbul karena adanya ketidakseimbangan dalam tubuh dalam hal ini kebutuhan untuk menggunakan kondom, menggunakan pelayanan kesehatan dan memilih pelanggan timbul karena adanya tujuan untuk terhindar dari penyakit HIV/AIDS (tetap sehat) selain itu adanya insentif yang diberikan dapat meningkatkan motivasi WPS untuk melakukan pencegahan HIV/AIDS. Kebutuhan timbul karena adanya ketidakseimbangan dalam tubuh dalam hal ini kebutuhan untuk menggunakan kondom, menggunakan fasilitas pelayanan kesehatan dan memilih pelanggan timbul karena adanya tujuan untuk terhindar dari penyakit HIV/AIDS (tetap sehat) selain itu adanya insentif yang diberikan dapat meningkatkan motivasi WPS untuk melakukan pencegahan HIV/AIDS. Kebutuhan timbul bila adanya ketidakseimbangan antara apa yang dimiliki dengan apa yang seharusnya dimiliki, baik dalam arti fisiologis maupun psikologis, manusia terdorong untuk berprilaku untuk mencapai tujuannya sehingga tercapai keseimbangan lebih fokusnya jika dikaitkan 
dengan teori ${ }^{18}$ berada pada tahap kebutuhan akan bebas dari bahaya yang mana penyakit HIV/AIDS disebut sebagai penyakit berbahaya karena belum ada obatnya sehingga menjadi pendorong WPS untuk melakukan pencegahan HIV/AIDS dengan tujuan WPS bisa tetap bekerja dengan kondisi sehat. ${ }^{19}$ Sedangkan insentif yang mampu memotivasi WPS bukan hanya berupa finansial (materi) tetapi juga bisa berupa non materi meliputi pujian, penghargaandan ucapan terimakasih sehingga insentif digunakan sebagai alat untuk meningkatkan motivasi untuk melakukan pencegahan HIV/AIDS tujuan yang telah ditentukan sebelumnya. ${ }^{20}$

Sikap dalam Pencegahahn HIV/AIDS $\left(\xi_{1}\right)$ Berpengaruh Tidak Langsung terhadap Perilaku Pencegahan HIV/AIDS WPS $\left(\eta_{2}\right)$ melalui Motivasi $\left(\mathbf{\eta}_{1}\right)$

Sikap seseorang dapat berubah dengan diperolehnya tambahan informasi. Sikap merupkan hal yang penting dalam kehidupan sehari-hari, bila sikap itu sudah terbentuk dalam diri seseorang selanjutnya akan ikut menentukan tingkah lakunya terhadap sesuatu. Pengetahuan dan pemahaman seseorang tentang sesuatu hal akan berpengaruh terhadap sikap, dan sikap tersebut selanjutnya mempengaruhi adanya niat seseorang untuk melakukan tindakan atau berperilaku.

Berdasarkan uji statistik dengan menggunakan PLS diperoleh koefisien jalur $0,503 \times 0,345 \mathrm{t}$ statistik 4,619>1,96 dan 7,032 $>1,96$ pada CI $95 \%$ sehingga dapat disimpulkan bahwa sikap dalam mencegah HIV/AIDS berpengaruh positif dan signifikan terhadap perilaku pencegahan HIV/AIDS WPS melalui motivasi dengan besarnya pengaruh $5,66 \%$.

Hasil penelitian ini sesuai dengan penelitian yang telah dilakukan sebelumnya ${ }^{17}$ bahwa responden yang memiliki kesadaran (sikap) yang tinggi tentang resiko bahwa dirinya dapat tertular HIV/AIDS maka responden akan termotivasi untuk melakukan pencegahan HIV/AIDS dengan menggunakan kondom saat berhubungan seksual. Begitupun responden yang memiliki pendapat (sikap) positif tentang tes VCT dan memandang bahwa layanan VCT sangat penting untuk mengetahui status HIVseseorang maka responden juga termotivasi untuk melakukan VCT.

Terbentuknya suatu sikap banyak dipengaruhi oleh faktor perangsang yang timbul di lingkungan sosial dan juga kebudayaan misalnya keluarga, norma, adat istiadat dan kepercayaan. Sikap seseorang tidak selalu menjelma dalam bentuk perbuatan atau tingkah laku tindakan.Sikap akan diikuti atau tidak diikuti oleh tindakan, mengacu kepada pengalaman orang lain. ${ }^{21}$

Hasil penelitian ini dapat mengkonfirmasi teori Planned Behavior bahwa sikap dapat berpengaruh terhadap perilaku yang diawali

dengan adanya niat untuk melakukan atau yang memotivasi sehingga semakin tinggi sikap (positif) maka akan semakin tinggi motivasi untuk berprilaku. Dalam hal ini maka semakin tinggi sikap dalam pencegahan HIV/AIDS maka akan semakin tinggi motivasi untuk melakukan pencegahan HIV/AIDS. ${ }^{7}$

\section{Dukungan Teman Sesama WPS 9 Berpengaruh Tidak Langsung terhar Perilaku Pencegahan HIV/AIDS WPS $\left(n_{2}\right)$ melalui Motivasi $\left(\boldsymbol{n}_{1}\right)$}

Terdapat dua macam dukungan yaitu dukungan naturaldan dukungan artificial. Dukungan natural merupakan dukungan yang diperoleh dari orang- orang terdekat termasuk keluarga dan teman dekat. Sedangkan sumber dari dukungan artificial adalah sumber dukungan yang dengan sengaja dibentuk untuk memberikan bantuan seperti dukungan kelompok, konselor dan tenaga kesehatan. ${ }^{2}$

Berdasarkan uji statistik dengan menggunakan PLS diperoleh koefisien jalur $0,477 \times 0,345 \mathrm{t}$ statistik $2,1856>1,96$ dan $6,4052>1,96$ pada CI $95 \%$ sehingga dapat disimpulkan bahwa dukungan teman sesama WPS berpengaruh positif dan signifikan terhadap perilaku pencegahan HIV/AIDS WPS dengan besarnya pengaruh 5,37\% .

Hasil penelitian ini sesuai dengan penelitian kualitatif $^{15}$ dari pernyataan empat informan yang menyatakan bahwa salah satu faktor yang memotivasi mereka untuk melakukan pencegahan HIV/AIDS maupun Voluntary Counselling and Testing (VCT) adalah dari teman - teman mereka sendiri.

Pengaruh dukungan sosial (dukungan teman sesama WPS) baik dalam bentuk emosional, informasi, instrumental atau kontrol terhadap kesehatan dapat meningkatkan koping adaptif sehingga WPS dapat menghadapi bahkan menyelesaikan masalah atau keluhan yang ada dalam dirinya yang ditandai dengan tumbuhnya motivasi yang ditandai dengan bangkitnya semangat untuk tetap hidup dan 
selalu optimis untuk tetap melakukan pencegahan HIV/AIDS sehingga dapat meningkatkan kualitas hidup. Karena pada dasarnya motivasi dapat meningkatkan kualitas hidup. Upaya yang dapat dilakukan untuk pencegahan HIV/AIDS adalah dengan penemuan kasus sedini mungkin, salah satunya adalah dengan pemeriksaan HIV/AIDS dengan cara memberikan motivasi pada kelompok subpopulasi (WPS) untuk melakukan pemeriksaan HIV/AIDS. ${ }^{2}$

\section{Kesimpulan}

Dengan CI 95\% dan pengujian hipotesis dengan Structural Equation Model (SEM) menggunakan SmartPLS didapat bahwa sikap dalam pencegahan HIV/AIDS, dukungan teman sesama wanita pekerja seks (WPS) dan motivasi berpengaruh baik secara langsung maupun secara tidak langsung melalui motivasi terhadap perilaku pencegahan HIV/AIDS WPS dengan besarnya pengaruh sikap dalam pencegahan HIV/AIDS 37,7\%, dukungan teman sesama WPS $22,9 \%$, motivasi $32,7 \%$. Sedangkan besarnya masing-masing pengaruh sikap dalam pencegahan HIV/AIDS dan dukungan teman sesama WPS terhadap perilaku pencegahan HIV/AIDS WPS melalui motivasi yaitu 5,66\% dan 5,37.

\section{Saran}

Bagi Puskesmas setempat dan LSM Bandungwangi diharapkan untuk lebih memberikan pengertian dan pemahaman pada WPS dengan meningkatkan intensitas penyuluhan untuk penyebaran informasi secara lengkap agar meningkatkan kesadaran sehingga memiliki sikap baik dalam pencegahan HIV/AIDS. Selain itu, diharapkan dapat melakukan pendekatan yang tepat kepada WPS sehingga dapat memantau perilaku berisiko yang dilakukan oleh WPS dan membuat suatu intervensi untuk mengubah perilaku berisiko tersebut. Melakukan monitoring penggunaan kondom bagi setiap WPS juga perlu dilakukan sehingga bisa menyediakan jumlah kondom yang dibutuhkan WPS dan ddilakukan upaya untuk menguatkan bargaining position WPS dalam penggunaan kondom. Selain itu, mengenalkan klinik VCT dan jadwal pemeriksaan serta melakukan monitoring dan evaluasi terhadap penyuluhan maupun kegiatan-kegiatan yang dilakukan terkait dengan HIV/AIDS pada WPS.
Bagi penelitian selanjutnya dapat memperluas objek penelitian dan menambah variabel lain yang secara teori berpengaruh terhadap perilaku.

\section{Daftar Pustaka}

1. Noviana. Catatan Kuliah HIV/AIDS. Jakarta: TIM; 2013.

2. Setyoadi. Strategi Pelayanan Keperawatan Bagi Penderita AIDS. Yogyakarta: Graha Ilmu; 2012

3. KPAN. Rangkuman Eksekutif Upaya Penanggulangan HIV dan AIDS di Indonesia 2006-2011

(http://www.aidsindonesia.or.id/repo/ExSumL ap5thnInd.pdf) diunduh 2 Desember 2013

4. Silalahi RE. Pengaruh Faktor Predisposisi, Pendukung dan Penguat Terhadap Tindakan Pekerja Seks Komersial (PSK) dalam Menggunakan Kondom untuk Pencegahan HIV/AIDS di Lokalisasi Teleju Kota Pekanbaru Tahun 2008. Medan: Sekolah Pascasarjana.USU

(http://repository.usu.ac.id/bitstream/12345678 9/6819/1/08E00920.pdf) diunduh 3 November 2013.

5. Ditjen PP \& PL Kementrian Kesehatan RI. 2013. Laporan Situasi Perkembangan HIV/AIDS di Indonesia Tahun 2013 (http://www.aidsindonesia.or.id/ck_uploads/fil es/Laporan\%20HIV\%20AIDS\%20TW\%201\% 202013\%20FINAL.pdf ) diunduh 2 Januari 2014.

6. Notoatmodjo S. Ilmu Perilaku Kesehatan. Jakarta: Rineka Cipta; 2010.

7. Ajzen I. Attitude, Personality and Behavior Second Edition. Milton-Keynes, England: Open University Press/McGraw-Hill; 2005.

8. Karyati, Sri. Faktor-Faktor yang Mempengaruhi Konsistensi Pemakaian Kondom Wanita Penjaja Seks dalam Pemakaian Kondom untuk Mencegah Penularan PMS dan HIV di Pati. UI, 2001 (http://lontar.ui.ac.id/file?file=digital/202 82520-T\%20Sri\%20Karyati.pdf) diunduh 8 Desember 2013.

9. Prasetyo F Proses Negosiasi antara Pekerja Seks Komersial dengan Pelanggan dalam Pemakaian Kondom untuk Mencegah Penularan IMS dan HIV/AIDS: Studi Kasus di Lokalisasi Boker Ciracas Jakarta Timur. UI Jakarrta(http://lontar.ui.ac.id/opak/themes/libri 2/detail/jsp?=108153\&lokasi) diunduh 15 Januari 2014.

10. Nursalam. Asuhan Keperawatan pada Pasien Terinfeksi. Jakarta: Salemba Medika, 2013

11. KPAN. Hasil Survei Cepat Perilaku (SCP) WPS 2010. (www. Aidsindonesia.or.id/news/4478/19/04/2012/Ha 
sil-Survei-Cepat-Perilaku-(SCP) WPS 2010. sthash, li525Rb1.dpbs) diunduh 15 Desember 2013.

12. Widiyanto, dkk. Faktor-faktor Yang Berhubungan Dengan Praktik Wanita Pekerja Seks (WPS) dalam VCT Ulang di Lokalisasi Sunan Kuning Kota Semarang. Jurnal Promosi Kesehatan Indonesia. Januari 2009; 4(http://eprints.undip.ac.id/18484/1/S._GUNA WAN_WIDIYANTO.pdf) diunduh 10 Oktober 2013.

13. Mustafa dan Wijaya. Panduan Teknik Statistik SEM \& PLS dengan SPSS Amos. Yogyakarta: Cahaya Atma Pusaka, 2012

14. Sugiyono. Metode Penelitian Kuantitatif Kualitatif dan R\&D. Bandung: Alfabeta; 2009.

15. Wulansari, dkk. Studi Kualitatif Motivasi Pekerja Seks Komersial (PSK) dalam Pemanfaatan Voluntary Counselling and Testing di Desa Kopeng Kecamatan Getasan Kabupaten Semarang, 2012 perpusnwu.web.id di unduh 15 Januari 2014.

16. Ariani, dkk. Analisis Hubungan antara Pengetahuan, Sikap dengan Tindakan Berdasarkan Indikator Serveilans Perilaku HIV/AIDS pada Wanita Pekerja Seks (Studi Penelitian IMS Puskesmas Putat Jaya Surabaya). Departemen Epidemiologi FKM Unair; 2012.

17. Lestari, dkk. Faktor - Faktor yang Mempengaruhi Rendahnya Minat LSL di Kota Surakarta Untuk Melakukan Tes HIV Secara Sukarela (VCT ). Yayasan Gessang Surakarta. 2012

18. Uno H. Teori Motivasi dan Pengukurannya Analisis di Bidang Pendidikan. Jakarta: Bumi Aksara;2010.

19. Siagian S. Teori Motivasi dan Aplikasinya. Jakarta: Rineka Cipta; 2012.

20. Pasaribu H. Pengaruh Pelaksanaan Pemberian Insentif terhadap Motivasi Kerja Pegawai Dinas Pendapatan Provinsi Sumatera Utara. USU, 2008 (http:// repository. usu. ac. id/ handle /123456789 /4339) diunduh 15 Desember 2013.

21. Fatimah S. Hubungan antara Pengetahuan dan Sikap Pasien Infeksi Menular Seksual (IMS) dengan Perilaku Pencegahan Penularan IMS di Wilayah Kerja Puskesmas Kom Yos Sudarso Pontianak. Universitas Tanjungpura, 2013 (httpjurnal.untan.ac.idindex.phpjfkarticleview 37793783.pdf) diunduh 15 Januari 2014. 